ditions, have formed either a great delta, or a narrow arm of the sea into which the waters of the Indus and Euphrates drained. Such conditions would have admitted of the extension of species from one side to the other, which the later and more extensive depression of the area, as shown in Scinde, afterwards more completely shut off."

Amongst the more remarkable of the operculated landshells described by Col. Godwin-Austen is a new species of Tropidiphorus, which is proposed to be named $T$. Balfouri after its discoverer (Fig. 2).

The Reptiles collected by Prof. Balfour in Socotra have been worked out by Dr. Günther ${ }^{x}$ and Mr. W. T. Blanford Dr. Günther taking the Snakes and Amphisbanians, and Mr. Blanford ${ }^{2}$ the remaining Lacertilians. Both of these collections werefound to be of considerable interest. Among the snakes is a new form allied to Tachymenis, which Dr. Günther has proposed to call Ditypophis, and a new species of Zamenis ( $Z$. Socotra). Both these indicate an alliance with the circum-Mediterranean fauna. On the other hand the Socotran Sand-Asp (Echis colorata) belongs to an Arabian and Palestine species, while the Amphisbrena of Socotra (Pachycalamus brevis, gen. et sp. nov.) has its nearest allies in Eastern and Western Tropical Africa. Of the six species of lizards of which examples were in Mr. Blanford's series, three proved to be new to science.

At the same meeting of the Zoological Society Mr. Charles $\mathrm{O}$. Waterhouse read a paper on the Coleopterous Insects which had been collected by Prof. Bayley Balfour in Socotra. The number of species of which examples were collected was stated to be twenty-four, and showed that the fauna of Socotra, judging from this collection, was distinctly African. Twelve of the species were described as new to science.

It will be seen, therefore, that although the zoological collections made by Prof. Balfour were very small in each group-in some cases almost of a fragmentary character-the results in every case present features of great interest. It is obvious that, judging from what is thus known, Socotra must possess-what was thought scarcely probable by many at the time the scheme for exploring it was first started-an indigenous fauna of considerable extent, one well worthy of further investigation, which the Socotran Committee, we believe, are quite resolved to undertake if they can obtain the necessary means. As regards the flora of Socotra we have said nothing, because Prof. Balfour, who has himself undertaken the investigation of the botanical collections, has not yet completed his task. But a preliminary examination has shown, we believe, that his series embraces about I 50 absolutely new flowering plants, amongst which are from fifteen to twenty representatives of new genera -so that it is manifest that, like the fauna, the flora of Socotra possesses a strong autochthonous element. ${ }^{3}$ Of this we hope to be able to give some account when Prof. Balfour is further advanced in his work. Meanwhile there can be no question that the Socotran Committee have accomplished a most useful bit of work, and that in this case, at all events, the public money devoted to scientific research has been well applied.

\section{A GEOLOGIST'S NOTES ON THE ROYAL ACADEMY}

NLY of late years has the importance of accuracy in the drawing of rock structure been recognised either by artists or by the general public. For this we are indebted to no one so much as to Mr. Ruskin, whose chapters on the subject in the fourth volume of "Modern

I "Descriptions of the Amphisbærians and Ophidians collected by Dr. Bayley Balfour in the IsIand of Socotra " (Proc. Zool. Soc.. April 5, I88I). " "On the Lizands collected by Prof. Bayley Balfour in Socotra." (I.bid.) 3 A very fine new Begonia from Socotra, of which tubers brought home Botanical Magtazine, tab. 6553 .
Painters" should be read again and again by every student who considers the faithful representation of Nature not unworthy of the aims of Art. It is true that some of the greatest among the older masters-as Titian or Dürer-rendered with great spirit and considerable accuracy the more salient features of rock structure, but from one cause or another they seldom entered into details, and were rather prone to exaggeration. The majority, till almost the present time, appeared to consider themselves unfettered, and "improved" upon Nature in accordance with the fancied requirements of the principal theme of their pictures. Some of the results may. be seen in the volume to which we have referred. Within the last few years a due estimate of the special excellencies of Turner's work has produced a salutary influence, and more than one artist (like Elijah Walton, to speak only of the dead) has grappled successfully with the difficulties of rock structure. Thus the boulders, studied apparently from lumps of modeller's clay, the dilapidated crags, tottering like habitual inebriates, the attenuated peaks, which might have been decapitated with a walking-stick, are rapidly disappearing from the walls of our exhibitions. In many pictures however we still perceive more of good intention than of knowledge, and the number of those who cannot be said to "draw with the understanding" is by no means small.

We venture then to offer a few remarks on rocks as they are represented on the walls of the Royal Academy. In No. 13, "Gorse-cutting," passing clouds render the hillside in the background rather vague, but it may be doubted whether this is the only cause of an indefiniteness in the rock-structure, which is certainly also observable in that of the foregraund. 28, "Llyn and Nant Gwynant," exhibits much careful mapping-out of the rocks, but cannot otherwise be said to be successful. There is a want of character in the craggy hillside in 55 , "A Mountain Road," and the boulders are flat and indefinite, as though the artist had inserted them in bis studio when the memory of their appearance in the field was beginning to fade from his mind. The same inability to seize the dominant characteristics of the rocks appears in 80, "Waiting for the Ferry." In 85, however, the "Land of Streams," its artist has been much more successful. Mr. C. E. Johnson has given us a painstalking study of a mass of hard stratified rock, which, as it dips away from the spectator, forms outcropping, curving ledges, over which the water dashes. In these, and in the craglets, both in foreground and middle distance, the principal facts of bedding and jointing are accurately rendered. Not so, however, in 89, "The Head of Teesdale," where we are led to conclude that the rocks are modelled from the same material as those in the scenes of theatres. The artist of 98 , "A Storm in the Desert," has been more careful, but unless there is something exceptional in the locality it is difficult to conjecture what the rock may be. A mountain streaked with snow in the background of 122 , "A Sermon in the Hayfield," is carefully studied, but still is rather wanting in character, and the colouring strikes us as crude. Mr. C. E. Johnson has again been successful in "The White Sands of Iona" (I 88 ), which is a very careful rock study. Rough craglets either of granite or of the granitoid gneiss, common on the western coast of Scotland, crop out among the slopes of sand. Of some the upper parts are smooth and polished, exhibiting traces either of the action of glaciers, like many another reef around the Western Highlands, or possibly in this case an example of the gentler attrition of blown sand; the rocky knolls in the middle distance should also be noticed. "The Scapegoat" (2II) is a picture which causes us some little perplexity. There is an appearance of careful study both in the foreground craglets and in the bare mountains, which make up the scenery of this "Land not inhabited"; but still it is difficult to decide upon the 
actual character of the rock or the locality which the animal has reached. The great block in the foreground, upon which the scapegoat is standing, might be either a limestone or a felstone. The same rock constitutes the nearermountain, and this, judging from the peculiar way in which the dominant joint planes alter their direction, can only be igneous. Hence we must assume it to be a felstone with a rather platy jointing. If this be the case, then the mountaincrests are exceptionally sharp, and the structure to which this is due is insufficiently indicated. The same general character is maintained in the distant mountains, but these are even more jagged. The picture. suggests a combination of some Sinai photographs, rather imperfectly understood, with memories, which have become vague, of the Southern Alps. Might it not also be doubted whether such a waterfall as that on the right would occur in a "lone land" on the borders of Palestine? In the "Diamond Merchants"(258), if we do not wrongly identify the lighthouse on the distant skerries, the scene represented is in the immediate neighbourhood of the Land's End. The rock there should be granite, and the structure of the craglet in the foreground will accord with this, though the colour is unusual for that district; but the cliffs beyond much more resemble, especially in a sort of streakiness, some of the stratified rock locally called "killas." In "Past Work" (489), by the same arist, there is a similar uncertainty of treatment in the rocks, showing that he has not thought them worthy of that appreciative study which he has bestowed upon most matters connected with the sea. The locality of 271 , "The First to look out for the Homeward Bound," may be presumed to be also Cornwall; but the rocks belong to quite a new type, and if they are anything, must be some kind of hard mudstone. 315, "Mountain Tops," is bold in colouring and in design, but can scarcely be regarded as successful. The floating clouds and the strong shadow into which the hills are cast by the gleaming sky, naturally obscure their structure, but would hardly account for the streakiness which they exhibit, as though the picture had been finished by wiping it down with a brush parallel to the leading outlines of each peak. It reminds us of an exaggeration of one of Turner's views of Loch Coruisk. 317, "A Babbling Brook in Ochmore," though hung rather too high, shows a careful study of gently-inclined strata. Mr. Brett, in "St. Ives' Bay" (340), gives us an excellent study of some granite rock in the middle distance of his picture; but this artist's mastery of his subject is brought out better in "Golden Prospects" (445). In the foreground is a ruined craglet or miniature "tor" of granitea wonderfully truthful study; form, structure, texture of the rock, and the crisp crusting of dry lichens, perfectly rendered. The bald patches of granite amid the rough vegetation are admirably trutbful, as is the hazy light, which renders the more distant cliffs, massive as they really are, almost ethereal. Out at sea, if we mistake not, is the Longships Lighthouse and its dangerous reef. Those who in any way equal $\mathrm{Mr}$. Brett in his love for the Cornish coast will find it hard to tear themselves away from this picture of one of its grandest scenes. It may however be remarked that the general effect suggests a day early in the summer, but still the heather is in bloom. ${ }^{1}$ There is some good promise in the limestone hills in 475, "A Grecian Tomb," though the hazy evening light is favourable to the avoidance of difficulties. In the "Ramparts of Idwal" (406), the colour is rather too monotonous, but a knoll with ledges of rock cropping out through rough turf and in the bed of a streamlet is admirably rendered. The peculiar texture of certain rocks composed of indurated volcanic ash seems to have impressed itself upon the artist. In "Hope Deferred" (419) there is little character in the rock; that however in the foreground may only be intended for very hard

I While we were studying this picture a bystander described it to his companion as "No doubt the Needles idealised" earth. In "Lofoden" (485) Mr. E. T. Compton gives us a careful study of a rather massive schistose rock in the mountain in the middle distance, and of one more granitoid in the foreground. The jointed structure of the latter and rather scaly aspect of parts of the former are well rendered, and the general effect of the picture is truthfuk though the author has not selected for his subject one of the most characteristic parts of the Lofoden Islands. It would not be difficult to find a view like this in several spots on the mainland, but the wilder mountains of Hindö and Ost Vaagen are without a parallel in Scandinavia. Mr. C. Stuart's "Uncertain Weather" (507) is hung too high, but it appears to be a very careful study of the well-known crag overhanging the tarn in Cwm Buchan. In Mr. B. W. Leader's "Glyder Vawr" (52I) we have a careful study of the felstone crags in the upper part of that mountain. The somewhat curving surfaces of outcropping rock in the middle distance of the picture and the boulders in the foreground are well rendered. The peculiar effect which the artist has chosen - a sudden gleam of sunlight glinting upon wet surfaces, gives to the rock an exaggeratedly rugged structure. The effect may be truthful, but is certainly rare, and we may doubt whether it is wise to select one producing results so abnormal. A rock in the foreground of "O'er the Heather" (539).is spotty, muddy, and indefinite. An unfamiliar effect has been chosen in "Kynance Cori as it appeared one day last January" (564), for a thick coating of snow rests upon the rocks. It is hung rather high, but the author does not seem to us to have quite succeeded in catching the peculiar structure and weathering of serpentine. "Nature's Decay" (905) also suffers from being too higb. The pile of débrisearth and trunks and fallen branches-masks a good deal of the rock, but what is visible seems to be carefully drawn ; that in a more distant ravine appears a little conventional. Sir R. Collier, in his "Glacier of the Rhone" (984), gives us one of his usual careful studies of rock and ice. The outcropping ledges and scattered boulders among the rough herbage are carefully drawn, making a most truthful rendering of a portion of rugged mountain-side. It may however be doubted whether the ice in the lower part of a glacier could be so generally blue as it is here represented. "Boulders at Rest" (1352) has some good points about it. The granite crag is carefully studied, and the structure is well rendered, but the two "natural" arches have a rather artificial aspect, and certainly weaken the effect of the composition. The boulders beneath have their individuality remarkably well preserved, but the artist has not been so successful in rendering their texture, which is rather woolly. In "The Dead Sea from Engedi" (1360) the artist appears to have striven honestly but not very successfully to record the scene. The rocks exhibit a streakiness of dubious authenticity, and convey to one the impression that while the general effect was felt by him the reasons for it were not understood.

Several other pictures we have been obliged to leave unnoticed, either because the rocks are obviously quite a subordinate part (though from our point of view that is no reason why they should not be accurate), or because the picture has been hung so high that it cannot be properly studied, and criticism might be unjust to the artists. The water-colour drawings we have not yet examined.

T. G. BONNEY

\section{NOTES}

THE death is announced of Mr. John Blackwall, F.L.S., at Llanrwst, on May II, at the great age of ninety-two. He was elected a Fellow of the Linnean Society as far back as 1827 , and was nearly its oldest member. His principal work was a magnificent illustrated Monograph of the British Spiders, published by the Ray Society about twenty years ago. He also 